\title{
Seismic Assessment of an RC Building Using Pushover Analysis
}

\author{
Riza Ainul Hakim \\ Civil Engineering Department, \\ King Abdul-Aziz University, \\ Jeddah, Saudi Arabia \\ ainul7@yahoo.com
}

\author{
Mohammed Sohaib Alama \\ Civil Engineering Department, \\ King Abdul-Aziz University, \\ Jeddah, Saudi Arabia \\ sohaib.alama@hotmail.com
}

\author{
Samir A. Ashour \\ Civil Engineering Department, \\ King Abdul-Aziz University, \\ Jeddah, Saudi Arabia \\ sashour@kau.edu.sa
}

\begin{abstract}
Current research works and observations indicated that parts of the Kingdom of Saudi Arabia have low to moderate seismic regions. Major parts of buildings were designed only for gravity load and were poorly detailed to accommodate lateral loads. This study aims to investigate building performance on resisting expected seismic loadings. Two $3 \mathrm{D}$ frames were investigated using pushover analysis according to ATC-40. One was designed according to a design practice that considers only the gravity load and the other frame was designed according to the Saudi Building Code (SBC-301). Results showed that the building designed considering only the gravity load was found inadequate. On the other hand, the building designed according to SBC-301 satisfies the Immediate Occupancy (IO) acceptance criteria according to ATC-40.
\end{abstract}

Keywords-pushover; seismic analysis; capacity spectrum; SBC301; ATC-40

\section{INTRODUCTION}

The Kingdom of Saudi Arabia lies within a low to moderate seismic region. According to the U.S. Global Survey (USGS) data, earthquakes have been detected recently in Tabuk (2009) and Gizan (2013). In the past decades, the inclusion of dynamic loads in the design of buildings in Saudi Arabia was limited to important huge structures. Recently, the Saudi Building Code (SBC-301) has been released for trial application. This code provides minimum load requirements for the design of buildings and other structures.

Most of existing buildings do not meet the current design standards due to design shortage or construction shortcomings. There are various reasons such as the lack of a national code, the noncompliance with applicable code requirements, the updating of codes, the design practices and changes in the use of buildings. Therefore, existing buildings should be evaluated regarding their capacity for resisting expected seismic effects before rehabilitation works [1].

It is believed that the conventional elastic design analysis method cannot capture many important aspects that affect the seismic performance of the building. The ability of a building to undergo inelastic deformations determines the structural behavior of building during seismic ground motions. For that reason, the evaluation of a building should be based on the inelastic deformation applied demanded by an earthquake, besides the stresses induced by the equivalent static forces as specified in seismic regulations and codes $[2,3]$.

Nonlinear dynamic analysis is a principally convenient approach. However, it is very complex and not practical for every design. Such analysis faces certain difficulties, such as the complexity of the three dimensional modeling structure, uncertainty of the structural properties, and the randomness of the ground motion data required for analysis. From the practical point of view, this method is not suitable for every design use, and for the time being it is mostly appropriate for research and design of important structure [4-6].

To estimate seismic demands for a building, the structural engineering profession is now using the non-linear static procedure, known as pushover analysis. It is a commonly used technique, which provides acceptable results. The term static implies that static analysis is applied to represent a dynamic phenomenon $[7,8]$.

Pushover analysis is a series of incremental static analysis carried out to develop a capacity curve for the building. This procedure needs the execution of a nonlinear static analysis of the structure that allows the monitoring of the progressive yielding of the structure component [3]. The building is subjected to a lateral load. The load magnitude increases until the building reaches the targeted displacement. This target displacement is determined to represent the top displacement when the building is subjected to design level ground excitation.

Pushover analysis produces a pushover curve or capacity curve that presents the relationship between the base shear (V) and roof displacement $(\Delta)$. The Pushover curve depends on the strength and deformation capacities of the structure and describes how the structure behaves beyond the elastic limit $[3$, $6,8]$.

Structural response to ground motion during earthquake cannot be accurately predicted because of the complexity of the structural properties and ground motion parameters. In pushover analysis, a set of lateral displacement is used directly as design condition. The displacement is an estimate of the 
maximum expected response of the structure during ground motion $[2,3]$.

\section{A. Capacity Spectrum}

The building performance level can be determined by target displacement using the capacity spectrum method (ATC 40). The capacity spectrum method allows for a graphical comparison between the structure capacity and the seismic demand. The pushover curve represents the lateral resisting capacity and the response spectrum curve represents the seismic demand.

The capacity spectrum method, which is described in Figure 1 , is started by producing a force-displacement curve that consider the inelastic condition. The result is then plotted to ADRS (Acceleration Displacement Response Spectrum). The demand is also converted into ADRS format so that the capacity curve and the demand curve are in the same format [9, $12]$.

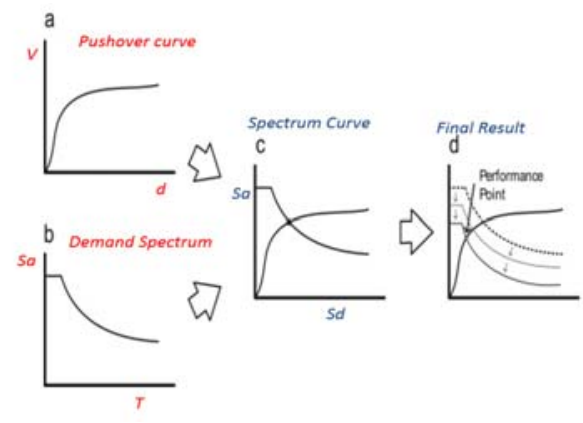

Fig. 1. Capacity spectrum method.

The general process for converting the capacity curve to capacity spectrum is to first calculate the modal participation factor (MPF1) and the modal mass coefficient $(\alpha)$, using the following equations:

$$
\begin{gathered}
\operatorname{MPF}_{1}=\frac{\sum \mathrm{m}_{\mathrm{i}} \varphi_{\mathrm{i} 1}}{\sum \mathrm{m}_{\mathrm{i}} \varphi_{i 1}^{2}} \\
a=\frac{\left[\sum \mathrm{m}_{\mathrm{i}} \varphi_{\mathrm{i} 1}\right]^{2}}{\left[\sum_{i=1}^{N} \frac{w_{i}}{g}\right] \cdot\left[\sum_{i=1}^{N} \mathrm{~m}_{\mathrm{i}} \varphi_{i 1}^{2}\right]}
\end{gathered}
$$

Where:

$\frac{w_{i}}{g}=$ mass assigned to level $\mathrm{i}$

$\varphi_{i 1}=$ amplitude of mode 1 at level $\mathrm{i}$

$\mathrm{N}=$ level $\mathrm{N}$

Then $S_{a}$ and $S_{d}$ are calculated for every point on the capacity curve using the following equations:

$$
\frac{\mathrm{S}_{\mathrm{a}}}{\mathrm{g}}=\frac{\mathrm{V}_{\mathrm{b}}}{\mathrm{W}} \cdot \frac{1}{a}
$$

$$
\mathrm{s}_{\mathrm{d}}=\frac{\Delta_{\text {roof }}}{\mathrm{MPF}_{1} \cdot \varphi_{\text {roof }_{1}}}
$$

Where:

$\mathrm{V}=$ base shear

$\mathrm{W}=$ building load weight

$\Delta_{\text {roof }}=$ roof displacement

To convert a demand spectrum from $\mathrm{Sa}$ and $\mathrm{T}$ format to ADRS format, it is required to calculate the value of $S_{d}$ for each point of the curve using the following equation:

$$
\mathrm{S}_{\mathrm{d}}=\frac{\mathrm{T}^{2} \mathrm{~S}_{\mathrm{a}}}{4 \pi^{2}}
$$

The performance point is obtained by superimposing demand spectrum on capacity curve into spectral coordinate or ADRS format. The capacity spectrum method has been built in SAP2000 program.

According to ATC 40, the performance levels of buildings are as shown in Table I.

TABLE I. PERFORMANCE LEVEL OF BUILDING

\begin{tabular}{|l|l|}
\hline \multicolumn{1}{|c|}{ Level } & \multicolumn{1}{|c|}{ Description } \\
\hline Operational & $\begin{array}{l}\text { Very light damage, no permanent drift, structure } \\
\text { retains original strength and stiffness, all systems are } \\
\text { normal }\end{array}$ \\
\hline $\begin{array}{l}\text { Immediate } \\
\text { Occupancy }\end{array}$ & $\begin{array}{l}\text { Light damage, no permanent drift, structure retains } \\
\text { original strength and stiffness, elevator can be } \\
\text { restarted, Fire protection operable }\end{array}$ \\
\hline Life Safety & $\begin{array}{l}\text { Moderate damage, some permanent drift, some } \\
\text { residual strength and stiffness left in all stories, } \\
\text { damage to partition, building may be beyond } \\
\text { economical repair }\end{array}$ \\
\hline $\begin{array}{l}\text { Collapse } \\
\text { Prevention }\end{array}$ & $\begin{array}{l}\text { Severe damage, large displacement, little residual } \\
\text { stiffness and strength but loading bearing column and } \\
\text { wall function, building is near collapse }\end{array}$ \\
\hline
\end{tabular}

\section{B. Nonlinear Plastic Hinge}

Pushover Analysis requires the development of the forcedeformation curve for the critical section of beams and column by using the guideline in [10]. Such a curve is presented in Figure 2.

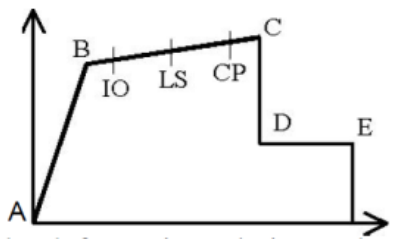

Fig. 2. Typical Load-deformation relation and target performance level

Point A corresponds to the unloaded condition. Load deformation relation shall be described by the linear response from $\mathrm{A}$ to an effective yield $\mathrm{B}$. Then the stiffness reduces from point $\mathrm{B}$ to $\mathrm{C}$. Point $\mathrm{C}$ has a resistance equal to the nominal strength then a sudden decrease in lateral load resistance to point $\mathrm{D}$, the response at reduced resistance to $\mathrm{E}$, final loss of resistance. The slope of the $\mathrm{BC}$ line is usually taken between 0 and $10 \%$ of the initial slope. The CD line corresponds to an 
initial failure of the member. The DE Line represents the residual strength of the member. These points are specified according to FEMA to determine hinge rotation behavior of RC members. The points between $\mathrm{B}$ and $\mathrm{C}$ represent acceptance criteria for the hinge, which is Immediate Occupancy (IO), LS (Life Safety), and CP (Collapse Prevention).

\section{DESCRIPTIVE OF THE BUILDING TEST}

The prototype building is a 6-story reinforced concrete structure, with a height story of $4.0 \mathrm{~m}$. The overall plan is $18 \times 18$ square meters. Figure 3 shows the typical structural layout. All beams are 600/400. The columns are 500/500 mm rectangular. The type of soil is soft rock or site class $\mathrm{C}$ according to the Saudi Building Code 301.

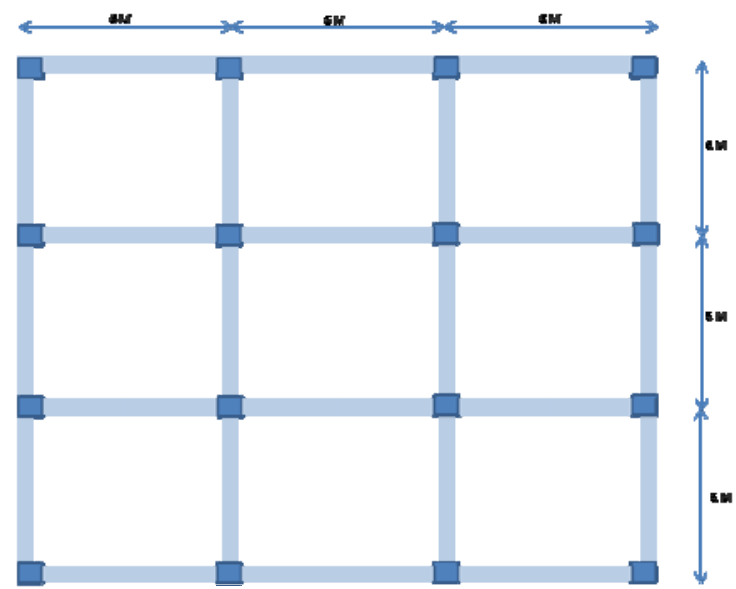

Fig. 3. Structure layout

The structural system was designed using two methods, the first is a design practice that considers only the gravity load whereas the intermediate resisting frame (IMRF) according to SBC 301 was considered for the second. A summary of the model's assumption is presented in Table II.

In this study, pushover analysis is carried out using the SAP2000 program. A three-dimensional model of structure has been created as shown in Figure 4. Beams and columns are modeled as nonlinear frame elements at the start and the end of element. The FEMA 356 rule, which is built in SAP 2000 with the IO, LS, and CP limit states for hinge rotation have been used for the acceptance criteria. The pushover analysis is executed separately for the two designs. The pushover analysis is achieved using a displacement control strategy, where the building is subjected to the lateral load pattern until the roof displacement reaches a target value. The minimum number of state used is 10 and the maximum is 100 .

Pushover analysis is performed in Haql, which is the most severe seismic zone according to SBC-301 [11] and the type of soil is soft rock or site class C. A summary of seismic site parameters are presented in Table III.
TABLE II. ASSUMPTIONS OF THE MODEL

\begin{tabular}{|c|c|}
\hline Material & \\
\hline Concrete & $27.5 \mathrm{MPa}$ \\
\hline Steel & A615Gr60 \\
\hline Loading & Automatically by Software \\
\hline Self-weight & $2.7 \mathrm{kN} / \mathrm{m}^{2}$ \\
\hline Dead load & $2.5 \mathrm{kN} / \mathrm{m}^{2}$ \\
\hline Live Load & Not Considered \\
\hline Wind Load & Sinear element for beam and column \\
\hline Modelling & Shell element for slab \\
\hline Element & Shell element for slab \\
\hline P-delta effect & Fixed \\
\hline Diaphragm & \\
\hline Support &
\end{tabular}

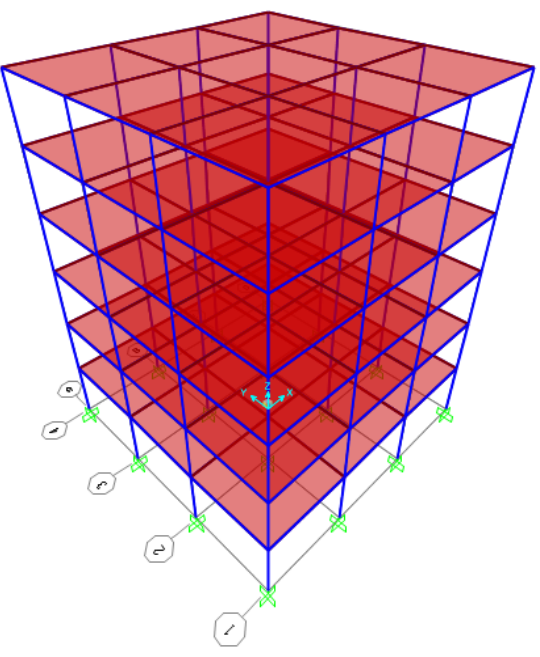

Fig. 4. 3D model (SAP2000)

TABLE III. SITE PARAMETERS

\begin{tabular}{|c|c|c|c|c|c|c|c|}
\hline $\mathbf{S}_{\mathbf{S}}$ & $\mathbf{S}_{\mathbf{1}}$ & $\mathbf{F}_{\mathbf{a}}$ & $\mathbf{F}_{\mathbf{v}}$ & $\mathbf{S}_{\mathbf{M S}}$ & $\mathbf{S}_{\mathbf{M} 1}$ & $\mathbf{S}_{\mathbf{D S}}$ & $\mathbf{S}_{\mathbf{D} 1}$ \\
\hline 0.865 & 0.281 & 1.054 & 1.519 & 0.912 & 0.427 & 0.608 & 0.285 \\
\hline
\end{tabular}

Where:

$\mathrm{S}_{\mathrm{S}}$ : the maximum spectral response acceleration at short periods $\mathrm{S}_{1}$ : the maximum spectral response acceleration at a period of $1 \mathrm{sec}$ $\mathrm{F}_{\mathrm{a}}$ : acceleration-based site coefficient $\mathrm{F}_{\mathrm{V}}$ : velocity-based site coefficient

$\mathrm{S}_{\mathrm{MS}}$ : the maximum spectral response acceleration at short periods adjusted for site class

$\mathrm{S}_{\mathrm{M} 1}$ : the maximum spectral response acceleration at a period of $1 \mathrm{sec}$ adjusted for site class

$\mathrm{S}_{\mathrm{DS}}$ : the design spectral response acceleration at short periods $\mathrm{S}_{\mathrm{D} 1}$ : the design spectral response acceleration at a period of $1 \mathrm{sec}$

SBC-301 provides the required minimum standards for the equivalent lateral force procedure of seismic analysis of a structure as presented in Table IV. The design response spectrum is developed as indicated in Figure 5. 
TABLE IV. SEISMIC DESIGN PARAMETER

\begin{tabular}{|c|c|c|c|c|c|c|}
\hline $\mathbf{R}$ & $\mathbf{I}$ & $\mathbf{H}$ & $\mathbf{T}_{\mathbf{a}}(\mathbf{s})$ & $\mathbf{C s}$ & $\mathbf{W} \mathbf{( k N )}$ & $\mathbf{V ~ ( k N )}$ \\
\hline 4 & 1 & 12 & 0.412 & 0.152 & 9227.0 & 1402.1 \\
\hline
\end{tabular}

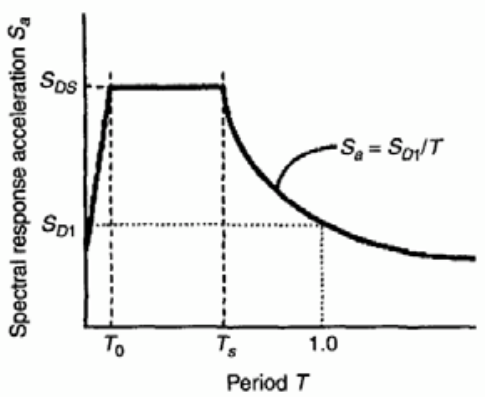

Fig. 5. Design response spectrum

\section{ANALYSIS RESULTS}

Pushover curves for the building for both designs are presented in Figure 6. These curves represent the global behavior of the frame with stiffness and ductility. Under incrementally increasing lateral load, the structural element may be yield sequentially. At every step, the structure experience loss in stiffness. Therefore, the slope of the pushover curve is gradually decreasing.

The comparison of the pushover curve shows that the stiffness of frame is larger in IMRF (SBC301) compared to the gravity load design. This means that SBC design has a greater capability to resist lateral load (seismic load) than the gravity load design.

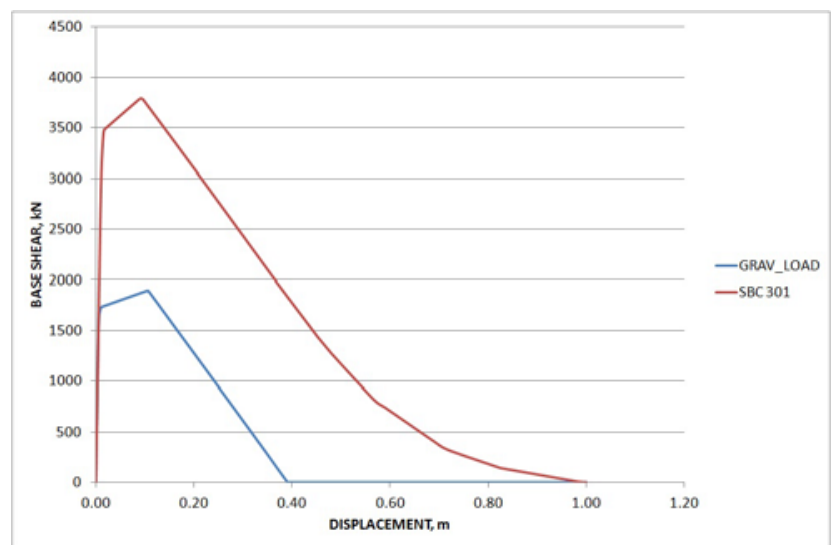

Fig. 6. Pushover curve

The performance point has been obtained by superimposing the demand spectrum on the capacity curve into spectral coordinates as shown in Figures 7 and 8.

At every deformation step of the pushover analysis determine plastic rotation hinge location in the elements and hinges reach the FEMA limit state, which are IO, LS, and CP using colors for identification (Figures 9 and 10). The steps at which the three limit states of plastic hinges are reached and the corresponding values on the pushover curve are obtained from Figure 7 and 8.

For gravity load design, the structural frame is not satisfactory because the lower columns yields exceed $\mathrm{C}$ (Collapse) condition. On the other hand, although most of elements in IMRF design are in yield condition, the damage of the structure is still limited since yielding occurs at event B (yielding) to IO (Immediate Occupancy).

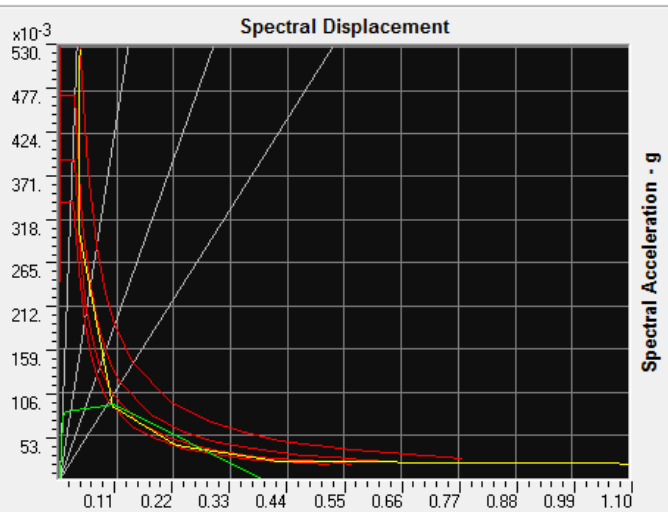

Fig. 7. Capacity spectrum for gravity load design

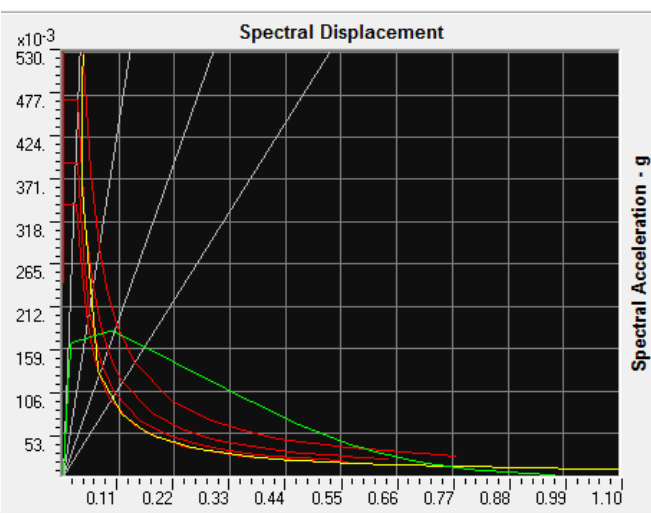

Fig. 8. Capacity spectrum for IMRF according to SBC
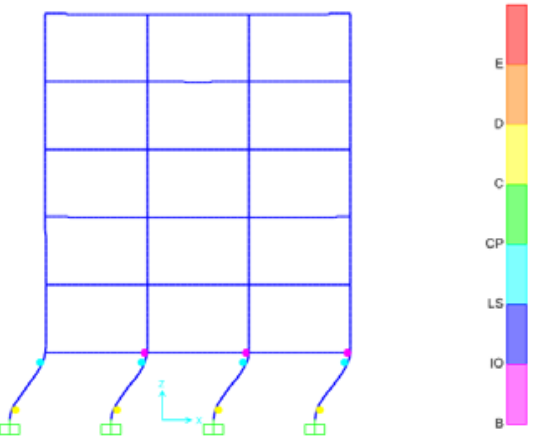

Fig. 9. Plastic hinge formation for gravity load design 

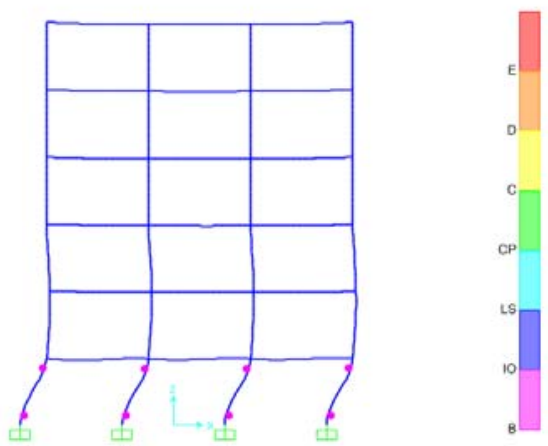

Fig. 10. Plastic hinge formation for IMRF design according to SBC

\section{CONCLUSION}

The test building is investigated using pushover analysis. These are conclusion obtained from this analysis:

- Pushover analysis can identify weak elements by predicting the failure mechanism and account for the redistribution of forces during progressive yielding. It may help engineers take action for rehabilitation work.

- Pushover analysis is an approximation method based on static loading. It may not accurately represent dynamic phenomena.

- The results show that design considering only gravity load is found inadequate. Therefore, a structural engineer should consider earthquakes in designing building.

- On the other hand, the building that was designed according to SBC-301 is satisfactory. The performance point location is at IO (Immediate Occupancy) level. It means the design satisfies pushover analysis according to ATC -40 .

\section{REFERENCES}

[1] M. S. Attar, "Evaluation of the Seismic Performance of A Typical School Building", M. S. Thesis, King Abdul Aziz University, Saudi Arabia, 2003

[2] M. N. Abd-alla, "Application of Recent Techniques of Pushover for Evaluating Seismic Performance of Multistory Building”, M. S. Thesis, Cairo University, Egypt, 2007

[3] P. I. Giannopoulos, "Seismic Assessment of RC Building according to FEMA 356 and Eurocode 8", 16th Conference on Concrete, TEE, ETEK, 21-23/10/2009

[4] A. Whittaker, G. Hart, C. Rojahn, "Seismic Response Modification Factors", Journal of Structural Engineering, Vol. 125, No. 4, pp. 438444, 1999

[5] A. K. Chopra, R. K. Goel, "A Modal Pushover Analysis Procedure to Estimate Seismic Demands for Unsymmetric-plan Buidings", Earthquake Engineering \& Structural Dynamics, Vol. 33, No. 8, pp. 903-927, 2004

[6] P. Poluraju, N. Rao, "Pushover Analysis of reinforced concrete frame structure using SAP 2000", International Journal of Earth Science and Engineering ISSN 0974-5904, Vol. 04, No. 06, pp. 684-690, 2011
[7] R. Martino, E. Spacone, G. Kingsley, "Nonlinear Pushover Analysis of RC Structures", Proceedings of Advanced Technology in Structural Engineering 2000, pp. 1-8, 2000

[8] A. Vijayakumar, D. L. V. Babu, "Pushover Analysis of Existing Reinforced Concrete Framed Structures", European Journal of Scientific Research, Vol.71, No. 2, pp. 195-202, 2012

[9] ATC-40: Seismic Evaluation and Retrofit of Reinforced Concrete Buildings: Applied Technology Council:1996

[10] FEMA-356: Prestandard and Commentary for The Seismic Rehabilitation of Buildings American Society of Civil Engineers, 2000

[11] The Saudi Building Code 301 Structural - Loading and Forces, The Saudi Code National Building Committee 2007.

[12] A. K. Chopra, R. K. Goel, "Capacity-Demand-Diagram Methods Based on Inelastic Design Spectrum”, Earthquake Spectra, Vol. 15, No. 4, pp. 637-656, 1999 